\title{
Assessing reintroduction success in long-lived primates through population viability analysis: western lowland gorillas Gorilla gorilla gorilla in Central Africa
}

\author{
Tony King, Christelle Chamberlan and Amos Courage
}

\begin{abstract}
The use of population modelling has become an increasingly common tool in reintroduction planning and assessment. Although initial reintroduction success is often measured by quantifying post-release survival and reproduction, longer-term success is best assessed through measurements of population viability. Here we develop a population model capable of providing useful results for influencing management of a reintroduction programme for a long-lived and slow-reproducing primate, the western lowland gorilla Gorilla gorilla gorilla. We used post-release monitoring data from two reintroduced populations in the Batéké Plateau region of Congo and Gabon, complemented with published data on wild and captive populations, to develop a population model using Vortex. Sensitivity testing illustrated that the model was highly sensitive to changes in the input parameters for annual birth rates, the number of lethal equivalents, and for female annual mortality rates, especially for adults. The results of the population viability analysis suggested that the reintroduced gorilla populations have a reasonable chance of persistence $(>90 \%$ over 200 years) but illustrated that reinforcement of the populations could significantly improve probabilities of population persistence and retention of genetic diversity. Equally, catastrophic events could have significant negative impacts. Continued monitoring of the populations should allow refinement of the model, improving confidence in its predictions and its relevance to decision-making.
\end{abstract}

Keywords Batéké Plateau, Congo, Gabon, Gorilla gorilla gorilla, population model, post-release monitoring, rehabilitation, reintroduction management

\section{Introduction}

The use of population modelling is becoming an increasingly common tool in reintroduction planning

Tony KING (Corresponding author) and CHristelle ChamberLan The Aspinall Foundation, BP 7170 Andravoahangy, Antananarivo 101, Madagascar. E-mail tonyk@aspinallfoundation.org

Amos Courage The Aspinall Foundation, Port Lympne Wild Animal Park, Hythe, Kent, UK

Received 29 May 2012. Revision requested 3 October 2012.

Accepted 10 October 2012. First published online 21 October 2013. and assessment (South et al., 2000; Armstrong \& Ewen, 2002; Armstrong \& Reynolds, 2012; Parlato \& Armstrong, 2012). Population models can be particularly helpful in assessing reintroduction success. Although initial reintroduction success is often measured by quantifying post-release survival and reproduction (Britt et al., 2004; Goossens et al., 2005; Maran et al., 2009; Tavecchia et al., 2009; King et al., 2012), the ultimate goal of a reintroduction is to re-establish a viable, self-sustaining population (IUCN, 2002; Beck et al., 2007). The probability of the long-term persistence of a reestablished population is best measured through modelling of population viability (Seddon et al., 2007, 2012). Another major role of population models is in guiding reintroduction decision-making (Armstrong \& Reynolds, 2012), including assessing potential reintroduction sites (Cramer \& Portier, 2001; Schadt et al., 2002) or potential release stock (Robert, 2009), estimating the number of release stock necessary or the required duration of the release period (Slotta-Bachmayr et al., 2004; Armstrong \& Seddon, 2008; Gusset et al., 2009; Schaub et al., 2009), evaluating the impacts on the source population (Bustmante, 1996; Somers, 1997; Todd et al., 2002; Kohlmann et al., 2005; Dimond \& Armstrong, 2007), and comparing potential management strategies (Armstrong et al., 2007; Wakamiya \& Roy, 2009; Martínez-Abraín et al., 2011).

Population viability models are, however, highly sensitive to the quality of the input data (South et al., 2000; Asbjørnsen et al., 2005). Accurate estimations of demographic parameters are particularly difficult to obtain for long-lived species (Harcourt, 1995; Gaillard et al., 1998; Robbins \& Robbins, 2004), and for the majority of reintroduced populations of any species because of low sample sizes (Nichols \& Armstrong, 2012). Consequently reintroduction programmes for several long-lived primate species (e.g. Yaeger, 1997; Tutin et al., 2001; Goossens et al., 2005; Strum, 2005; King \& Courage, 2008; Peignot et al., 2008) have yet to utilize population viability models in planning or assessment. A review of literature on modelling reintroduced populations (Armstrong \& Reynolds, 2012) analysed 89 papers, of which 46 concerned mammals but only one concerned a primate (Swart \& Lawes, 1996). This may to some extent be because of the geographical bias of publications, with most relating to projects in Europe, North America, New Zealand or Australia, where primates do not occur, and many models may not be published 
(Armstrong \& Reynolds, 2012). The model we develop here, for reintroduced western lowland gorillas Gorilla gorilla gorilla, appears to be the first published attempt to assess the long-term viability of a reintroduction programme for a long-lived and slow-reproducing threatened primate.

The western lowland gorilla is categorized as Critically Endangered on the IUCN Red List (Walsh et al., 2008) based on a projected $80 \%$ decline in the wild over three generations. The major causes of decline are commercial hunting and mortality caused by the Ebola virus (Tutin et al., 2005; Walsh et al., 2008), with habitat loss and degradation, and possibly climate change, expected to become major threats (Walsh et al., 2008). Gorillas can live for $>40$ years, usually do not reproduce until they are at least 10 years old, and females produce only one surviving offspring about every 5 years (Harcourt \& Stewart, 2007).

Two populations of western lowland gorillas are in the process of being re-established in the Batéké Plateau region of central Africa, one each in the neighbouring countries of the Republics of Congo and Gabon (King, 2004; King \& Courage, 2007, 2008; Pearson \& King, 2008). The first releases occurred in 1996 and 2001, respectively, in the two countries, and post-release monitoring data have recently been analysed to quantify demographic parameters, to allow an assessment of initial reintroduction success (King et al., 2012). This analysis illustrated that the reintroduction programme had been successful in terms of post-release survival, reproduction, and dispersal, with quantitative measures of these parameters being similar to comparable measures for wild populations (King et al., 2012). To assess longer-term success we use the demographic data for the reintroduced populations (King et al., 2012) and published data on wild and a few captive gorilla populations to develop a population model. We use the model to investigate how possible scenarios could affect the viability of the two reintroduced populations, and how population models can inform reintroduction management decisions for long-lived species.

\section{Methods}

\section{Study populations}

The two reintroduced western lowland gorilla populations are located in the Lesio-Louna Reserve of Congo and the Batéké Plateau National Park of Gabon (Fig. 1). Pre-release preparations and release implementation are described elsewhere (King et al., 2012). Both reintroduction sites have collaborative protected area management projects that arose from the development of the reintroduction programme, and the sites and the reintroduced populations have benefited from long-term post-release monitoring and surveillance (King, 2008; King \& Courage, 2008; King et al., 2012).

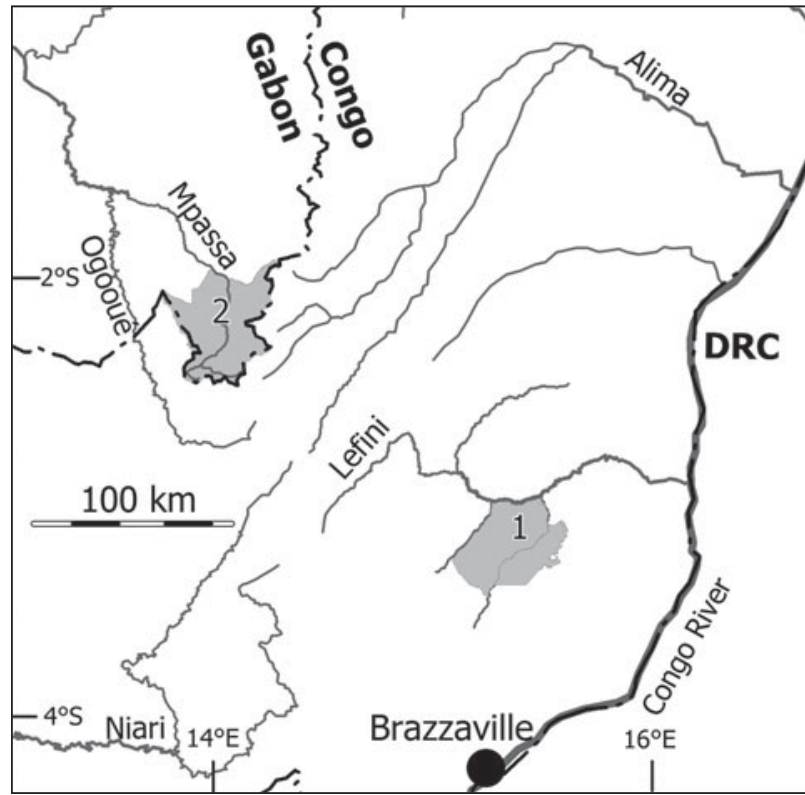

FIG. 1 The location of the two gorilla reintroduction sites (grey shading): the Lesio-Louna Reserve in Congo (1) and the Batéké Plateau National Park in Gabon (2), with major rivers and country borders.

Consequently, hunting pressure, which was identified as the main cause of the local extirpation of gorillas, has been dramatically reduced (King, 2008; King et al., 2012). A total of 51 gorillas ( 24 males, 27 females) were released between 1996 and 2006, 25 in Congo and 26 in Gabon, comprising 43 rehabilitated wild-born orphans, and one in situ and seven ex situ captive-born (King et al., 2005, 2009, 2012). In April 2009 total population sizes were 23 in Congo (comprising 15 wild-born and one in situ captive-born aged $8-22$ years, plus seven first-generation offspring aged 6 months -5 years) and 25 in Gabon (16 wild-born and six ex situ captive-born aged 7-13 years, plus three first-generation offspring aged 2 months -1.5 years). Further releases are expected at both sites (King \& Courage, 2008).

\section{Population modelling}

We used Vortex v. 9.94 (Lacy et al., 2003) to develop the population model for the reintroduced gorilla populations. Vortex is appropriate for modelling species with low fecundity and long lifespans (Miller \& Lacy, 2005) and is the most commonly used software in published reintroduction models (Armstrong \& Reynolds, 2012).

The demographic input parameters we used were based primarily on a combination of the results of the post-release monitoring of both reintroduced gorilla populations (King et al., 2012), compared with data on wild, or occasionally captive, western and eastern Gorilla berengei gorillas (Table 1). The calculation of some input parameters required further analysis of the post-release monitoring data from the 
TABLE 1 Parameters used for modelling populations of the western lowland gorilla Gorilla gorilla gorilla in the Lesio-Louna Reserve of Congo and the Batéké Plateau National Park of Gabon (Fig. 1), with the demographic input values used in the baseline scenario, values for the reintroduced populations based on post-release monitoring results, and rationale for the choice of each input value.

\begin{tabular}{|c|c|c|c|}
\hline Parameter & $\begin{array}{l}\text { Value used for } \\
\text { baseline scenario }\end{array}$ & $\begin{array}{l}\text { Value in reintroduced } \\
\text { population }\end{array}$ & Rationale \\
\hline $\begin{array}{l}\text { Mate monopolization } \\
\text { (\% of adult males in } \\
\text { breeding pool) }\end{array}$ & $\begin{array}{l}28.6 \%(=1 \text { per } \\
3.5 \text { females })\end{array}$ & & $\begin{array}{l}\text { Studies of } 5 \text { wild populations of western gorillas found median number of adult females per } \\
\text { predominantly single-male breeding group to be } 3.5 \text { (range of population means } 2.9-7.1 \text {; Harcourt \& } \\
\text { Stewart, 2007). }\end{array}$ \\
\hline Annual birth rate & 0.20 & $0.196^{1}$ & $\begin{array}{l}0.20 \text {, represented as } 20 \% \text { of adult females available to breed each year, with a maximum of } 1 \text { offspring per } \\
\text { female per year, is similar to the rates given by King et al. }(2012) \text { for reintroduced populations }(0.196) \text {, \& by } \\
\text { Robbins et al. (2004) for } 2 \text { wild populations of western gorillas }(0.198,0.180) \text {, \& for mountain gorillas } \\
(0.226) \text {. }\end{array}$ \\
\hline $\begin{array}{l}\text { Environmental variability in } \\
\text { annual birth rate }\end{array}$ & $2.4 \%$ & $2.4 \%^{2}$ & $\begin{array}{l}\text { Corresponds to the SD of annual birth rates in the reintroduced populations unaccounted for by the } \\
\text { expected SD because of demographic stochasticity. }\end{array}$ \\
\hline 1st age of breeding for females & 10 years & $\begin{array}{l}8.6-16.8 \text { years } \\
(\text { median } 10.3 \\
\text { mean } 11.6)^{1}\end{array}$ & $\begin{array}{l}10 \text { years reflects data for reintroduced populations; although not measured in wild western gorillas } \\
\text { (Robbins et al., 2004), female mountain gorillas, considered sexually mature from } 8 \text { years old, normally do } \\
\text { not give birth until c. } 10 \text { years old (Harcourt \& Stewart, 2007). }\end{array}$ \\
\hline 1st age of breeding for males & 13 years & $\begin{array}{l}11.5-15.0 \text { years } \\
(\text { median } 12.8)^{1}\end{array}$ & $\begin{array}{l}13 \text { years reflects data for reintroduced populations, \& in mountain gorillas the youngest known father was } \\
\text { just under } 12 \text { years old (Bradley et al., 2005). }\end{array}$ \\
\hline Maximum age of reproduction & 39 years & & $\begin{array}{l}\text { In wild female mountain gorillas age-related patterns in birth rates have been demonstrated, with an } \\
\text { apparent decrease from } 40 \text { (Robbins et al., 2006). There is evidence for menopause in captive female } \\
\text { western gorillas in their } 40 \text { s (Atsalis \& Margulis, 2006). }\end{array}$ \\
\hline Sex ratio at birth & $50: 50$ & $70: 30(\mathrm{M}: \mathrm{F})^{1}$ & $\begin{array}{l}\text { Appears to be no published data on sex ratio at birth for wild gorillas, \& data from reintroduced } \\
\text { populations are based on a small sample size; however, of } 114 \text { wild-born orphan western gorillas } \\
\text { (all of which were }<4 \text { years of age at time of capture) received at Projet Protection des Gorilles gorilla } \\
\text { sanctuaries in Congo \& Gabon between June } 1989 \text { \& December 2008, } 57 \text { were male \& } 57 \text { female } \\
\text { (The Aspinall Foundation, unpubl. data). }\end{array}$ \\
\hline $\begin{array}{l}\text { Annual mortality rate age } 0 \\
\text { (1st-year mortality) }\end{array}$ & $25 \%$ & $18.2 \%(1 \text { st generation })^{1}$ & $\begin{array}{l}\text { Published values for 1st-year mortality in wild gorillas vary ( } 8.3 \& 42.9 \% \text { for western gorillas, Robbins } \\
\text { et al., 2004; 19.6\%, Yamagiwa \& Kahekwa, 2001, \& } 24 \% \text {, Gerald, 1995, for eastern gorillas). The latter is } \\
\text { based on the largest sample size, \& we chose a value closest to this for the baseline. Our baseline values for } \\
\text { Ages } 0,1 \& 2 \text { combined result in a total infant mortality of } 33.7 \% \text {, similar to } 34 \% \text { infant mortality of } \\
\text { mountain gorillas (Watts, 1991; Gerald, 1995), \& within the range of two wild populations of western } \\
\text { gorillas ( } 22 \& 65 \% \text {; Robbins et al., 2004). }\end{array}$ \\
\hline Annual mortality rate ages & $6 \%$ & $0 \%(1 \text { st generation })^{1}$ & See above. \\
\hline
\end{tabular}

$1 \& 2$ (2nd \& 3rd year

annual mortality rate)

Annual mortality rate

ages 3-5 (juvenile

Values used in the baseline scenario for ages 3-11 are slightly higher than those given by King et al. (2012) annual mortality rate)

$1.2-1.5 \%$ (release stock $)^{1}$
Annual mortality rate ages 6-11

Annual mortality rate ages $12-17 \quad 2.5 \%(\mathrm{M})$ $1.7 \%(\mathrm{~F})$ for the reintroduced populations but give a deterministic total mortality for ages 3-11 of 14\%, as in a model developed for mountain gorillas (Robbins \& Robbins, 2004; both sexes combined) based on a relatively large data set for these age categories (Gerald, 1995).

See above.

Adult mortality data are limited for the reintroduced populations (1.2\% annual mortality rate for ages 8-21, after which no data are available; King et al., 2012), so we used the age-dependent sex-specific mortality rates from age 12 used by Robbins \& Robbins (2004) for a model developed for mountain gorillas. 


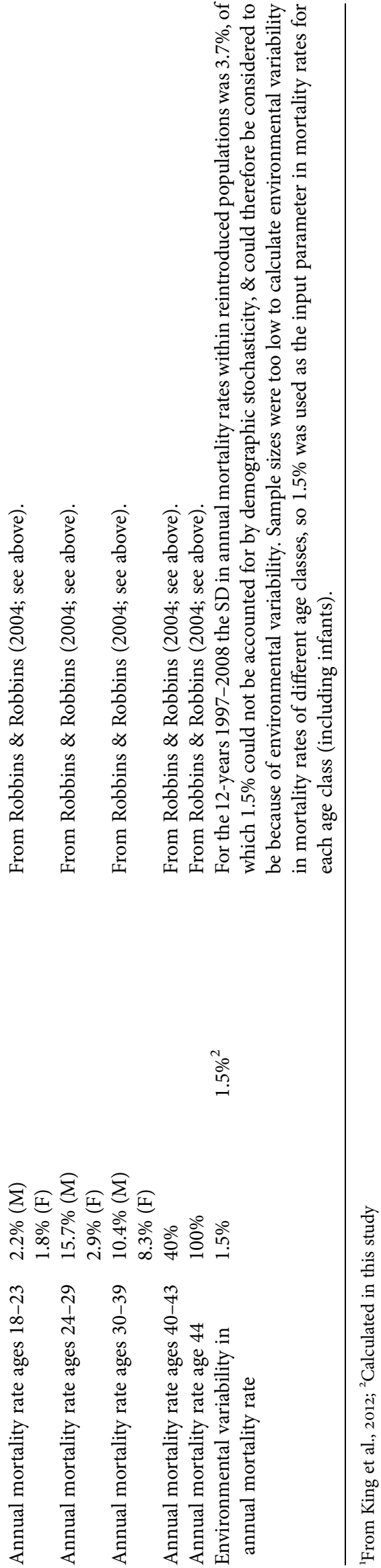

reintroduced populations, using the same dataset analysed by King et al. (2012), notably those relating to environmental variability $(\mathrm{EV})$. This was calculated following Miller \& Lacy (2005), using the equation: $s_{\mathrm{EV}}=\sqrt{ } s_{\mathrm{EV}}^{2}=\sqrt{ }\left(s_{\mathrm{TOT}}^{2}-s_{\mathrm{DS}}^{2}\right)$, where $s_{\mathrm{EV}}=$ the standard deviation because of $\mathrm{EV}$, $s_{\mathrm{EV}}^{2}=$ the variance because of $\mathrm{EV}, s_{\mathrm{TOT}}^{2}=$ the total variance across the data, and $s^{2}$ DS $=$ the sampling variance because of demographic stochasticity (DS) $=\left(p^{*}(1-p)\right) /(\mathrm{x}-1)$, where $p=$ the mean annual mortality rate and $x=$ the mean annual initial population size. As reproduction, like mortality, is also binary, we used the same method for calculating environmental variability in annual birth rates. We calculated this for 2003-2008, with one year (2006) excluded as it was an outlier showing an abnormally high birth rate that was clearly a function of the low sample size rather than of environmental variability (four females from a single group gave birth within 2 months of each other, from a total of seven females of breeding age with breeding opportunities within the population at that time).

We defined population extinction as only one sex remaining. Inbreeding depression was included in the baseline scenario using the default values in Vortex (3.14 lethal equivalents, with $50 \%$ because of lethal alleles). Environmental variation was considered to affect survival and reproduction independently. Reproduction was not considered to be density dependent, and carrying capacity was set at a high level (1,00o individuals per population) to avoid modelling density dependent impacts on population size (although the legally-defined reintroduction sites have a lower carrying capacity, in reality these sites are not isolated from surrounding habitat and we were interested to know the full potential for population growth regardless of legal habitat boundaries). The phenomenon of adult male dispersal from reproductive groups to become solitary and non-reproductive in the longterm (Harcourt \& Stewart 2007; King et al., 2012) was simulated in the model by specifying the reproductive system as long-term polygyny, and quantified through the mate monopolization parameter (Table 1).

The two reintroduced populations (in Congo and in Gabon) were modelled separately. The initial population sizes, structures and gene diversities were imported from studbooks for each population, as at April 2009 (excluding one recently born infant from each population whose sex was unknown at the time of the model development). We conducted a sensitivity analysis on the Congo baseline model, to identify the key vital rates requiring better estimates, by investigating the impact on the mean stochastic growth rate of using high and low values for various input parameters. For both populations we simulated the baseline model of no further releases, and five scenarios of varying reinforcement strategies (Table 2). The first reinforcement scenario $\left(R_{1}\right)$ modelled the inclusion of the gorillas in the pre-release phase of the programme in each country as at 
TABLE 2 Description of modelled scenarios of varying degrees of reinforcement on the baseline populations in Congo and Gabon.

\begin{tabular}{ll}
\hline Scenario & Description \\
\hline R1 & Reinforcement with individuals in pre-release phase as \\
& at April 2009 (Congo: 2 females \& 3 males aged 2-5; \\
& Gabon: 3 females \& 1 male aged 1-3) \\
R2 & R1 plus 1 group of 3 females \& 2 males aged 6 in year 7 \\
R3 & R1 plus 2 groups of 3 females \& 2 males aged 6 in years \\
& 7 \& 12 \\
R4 & R1 plus 3 groups of 3 females \& 2 males aged 6 in years \\
& $7,12 \& 17$ \\
R5 & R1 plus 4 groups of 3 females \& 2 males aged 6 in years \\
& $7,12,17$ \& 22 \\
\hline
\end{tabular}

April 2009, whereas subsequent reinforcement scenarios modelled hypothetical future releases based approximately on recent rates of arrivals of new gorillas at the rehabilitation centres (King et al., 2005, 2009). A probable scenario of reinforcement of the Congo population was chosen as a baseline for investigating the potential impacts of various catastrophes (Table 3). The first three catastrophe scenarios modelled potential disease outbreaks proposed by primate veterinarians for mountain gorillas Gorilla berengei berengei (Miller \& Lacy, 2005), and the fourth was intended to model potential outbreaks of an Ebola-like virus. Each scenario was run for 1,000 iterations over 200 years (rather than the more frequently used 100 years because of the relatively long generation time of the species).

The results we recorded for each simulation were deterministic population growth rate (deterministic $r$ ), stochastic population growth rate (stochastic $r$ ), probability of extinction over the 200 year model period $(\mathrm{P}(\mathrm{E})$ ), mean number of individuals in surviving populations (extant $\mathrm{N}$ ), and gene diversity (as a percentage of original diversity), plus standard deviations (SDs) as measures of variability.

\section{Results}

Sensitivity testing illustrated that the population model was highly sensitive to changes in the input parameters for annual birth rates, for the number of lethal equivalents, and for female annual mortality rates, especially for adults (Table 4). For example, a value of 0.18 for the annual birth rate rather than 0.20 as in the baseline model reduced the mean stochastic $r$ from 0.004 to -0.003 , resulting in an increase in the probability of extinction over 200 years from 9.2 to $29.3 \%$. Conversely, increasing the birth rate to 0.22 resulted in a mean stochastic $r$ of 0.010 and an extinction probability of $2.6 \%$.

The baseline model resulted in a deterministic population growth rate $(r)$ of 0.016 . In the baseline scenario of no population supplementation, the mean stochastic population growth rates $(r)$ were $0.004 \pm$ SD 0.053 and
$0.005 \pm$ SD 0.048 for the Congo and Gabon populations, respectively. Over 200 years this resulted in extinction probabilities of 9.2 and $4.9 \%$, mean extant population sizes of $82 \pm$ SD 73.7 and $104 \pm$ SD 80.3, and mean gene diversities of $77.0 \pm$ SD 11.7 and $80.2 \pm$ SD 10.5\% for the Congo and Gabon populations, respectively.

For both populations the model predicted that a single reinforcement with the gorillas in the pre-release phase of the programme in each country as at April 2009 (scenario R1) would have a considerable impact on the viability of the populations compared to the baseline scenario, reducing the probability of extinction over 200 years from 9.2 to $4.0 \%$ in Congo, and from 4.9 to $2.2 \%$ in Gabon (Table 5). Each subsequent reinforcement scenario modelled also improved viability, with both populations showing a $0 \%$ probability of extinction and a mean retention of genetic diversity of $>90 \%$ with scenarios $\mathrm{R}_{4}$ and $\mathrm{R}_{5}$ (Table 5).

The four modelled catastrophe scenarios each had major impacts on population persistence (Table 6). Compared to the probability of extinction of $1.8 \%$ for the baseline $\mathrm{R}_{2}$ scenario used, the four modelled catastrophe scenarios increased the probability of extinction to between 13.5 and $99 \%$. Gene diversity was also reduced.

\section{Discussion}

\section{Population viability analysis}

Our primary goal was to evaluate the long-term success of the western lowland gorilla reintroduction programme on the Batéké Plateau. The results from the baseline population viability analysis suggest that the reintroduced gorilla populations have a reasonable chance of persistence ( 91 and 95\% over 200 years, Congo and Gabon populations respectively) but that this probability could be significantly improved by further releases or reinforcements. However, our sensitivity analysis shows that this prediction can be dramatically altered through apparently small modifications of the input parameters to the model, particularly in birth rates, female mortality rates, and inbreeding depression estimates, and also through the inclusion of hypothetical catastrophic events. Some small modifications in demographic input parameters can increase the probability of persistence considerably, as does reducing the impact of inbreeding depression. Conversely, the inclusion of hypothetical catastrophes led to predictions of likely population extinction in all but one scenario.

In addition to population persistence over a specified time-frame, another aspect of population viability is the maintenance of adequate genetic diversity over the course of several generations (Lacy, 1997; Frankham et al., 2002; Goossens et al., 2002; Armstrong \& Seddon, 2008). Although some reintroduced populations have been 
TABLE 3 Description of modelled scenarios of various catastrophes on the R2 baseline population in Congo (scenarios $\mathrm{C}_{1}$, $\mathrm{C}_{2}$ and $\mathrm{C}_{3}$ were proposed by primate veterinarians for the mountain gorilla Gorilla berengei berengei; for more details see Miller \& Lacy, 2005).

\begin{tabular}{|c|c|c|c|c|}
\hline Scenario & Description & $\begin{array}{l}\text { Annual probability } \\
\text { of occurrence }(\%)\end{array}$ & $\begin{array}{l}\text { Reduction in } \\
\text { survivorship }\end{array}$ & $\begin{array}{l}\text { Reduction in } \\
\text { reproduction }\end{array}$ \\
\hline$\overline{\mathrm{C} 1}$ & Influenza-like disease & 10 & 5 & 0 \\
\hline $\mathrm{C} 2$ & Severe viral disease & 10 & 25 & 20 \\
\hline $\mathrm{C} 3$ & Viral disease with chronic cyclicity & 4 & 25 & 100 \\
\hline $\mathrm{C} 4$ & Ebola-like virus & 0.5 & 90 & 0 \\
\hline
\end{tabular}

TABLE 4 Sensitivity testing of the population model with low and high values of various input parameters, showing their impact on the mean annual stochastic population growth rate $r$.

\begin{tabular}{llcc}
\hline Input parameter & Low, Baseline, High & $r$ range & $r$ difference \\
\hline Annual birth rate & $0.18,0.20,0.22$ & $-0.003-0.010$ & 0.013 \\
Lethal equivalents & $1.0,3.14,5.0$ & $0.000-0.009$ & 0.009 \\
Female annual mortality rate (adult) & $\mathrm{B}-0.5, \mathrm{~B}, \mathrm{~B}+0.5 \%$ & $0.000-0.008$ & 0.008 \\
Female annual mortality rate (ages 1-9) & $\mathrm{B}-0.5, \mathrm{~B}, \mathrm{~B}+0.5 \%$ & $0.001-0.006$ & 0.005 \\
Female annual mortality rate (1st year) & $22.5,25,27.5 \%$ & $0.002-0.005$ & 0.003 \\
Maximum breeding age & $37,39,43$ years & $0.002-0.005$ & 0.003 \\
Mate monopolization & $3,3.5,7$ F : M ratio & $0.003-0.004$ & 0.001 \\
Male annual mortality rate (ages 1-12) & $\mathrm{B}-0.5, \mathrm{~B}, \mathrm{~B}+0.5 \%$ & $0.003-0.004$ & 0.001 \\
Male annual mortality rate (1st year) & $22.5,25,27.5 \%$ & $0.004-0.004$ & 0.000 \\
Male annual mortality rate (adult) & $\mathrm{B}-0.5, \mathrm{~B}, \mathrm{~B}+0.5 \%$ & $0.004-0.004$ & 0.000 \\
Environmental variability in adult female annual mortality rate & $\mathrm{B}-1, \mathrm{~B}, \mathrm{~B}+1 \%$ & $0.004-0.004$ & 0.000 \\
\hline
\end{tabular}

${ }^{*} \mathrm{~B}$, baseline value

TABLE 5 Summary of results (mean \pm SD) of the Vortex simulation of several scenarios of varying degrees of reinforcement of the baseline populations in Congo and Gabon over a 200-year period.

\begin{tabular}{|c|c|c|c|c|}
\hline & Stochastic $r^{1}$ & $\mathrm{P}(\mathrm{E})^{2}(\%)$ & Extant $\mathrm{N}^{3}$ & Gene diversity (\%) \\
\hline \multicolumn{5}{|c|}{ Congo population } \\
\hline Baseline & $0.004 \pm 0.053$ & 9.2 & $83 \pm 73.7$ & $77.0 \pm 11.69$ \\
\hline Scenario R1 & $0.005 \pm 0.047$ & 4.0 & $109 \pm 79.8$ & $81.1 \pm 10.92$ \\
\hline Scenario R2 & $0.007 \pm 0.043$ & 1.8 & $150 \pm 102.5$ & $85.3 \pm 7.33$ \\
\hline Scenario R3 & $0.009 \pm 0.041$ & 0.3 & $194 \pm 119.6$ & $88.0 \pm 5.56$ \\
\hline Scenario R4 & $0.010 \pm 0.039$ & 0.0 & $248 \pm 140.8$ & $90.3 \pm 3.90$ \\
\hline Scenario R5 & $0.011 \pm 0.039$ & 0.0 & $288 \pm 155.9$ & $91.5 \pm 3.12$ \\
\hline \multicolumn{5}{|c|}{ Gabon population } \\
\hline Baseline & $0.005 \pm 0.048$ & 4.9 & $104 \pm 80.3$ & $80.2 \pm 10.47$ \\
\hline Scenario R1 & $0.006 \pm 0.043$ & 2.2 & $133 \pm 96.2$ & $82.9 \pm 8.14$ \\
\hline Scenario R2 & $0.008 \pm 0.040$ & 1.0 & $181 \pm 112.3$ & $86.9 \pm 6.38$ \\
\hline Scenario R3 & $0.010 \pm 0.039$ & 0.2 & $230 \pm 131.2$ & $89.2 \pm 4.53$ \\
\hline Scenario R4 & $0.011 \pm 0.038$ & 0.0 & $275 \pm 149.3$ & $90.8 \pm 3.47$ \\
\hline Scenario R5 & $0.012 \pm 0.037$ & 0.0 & $326 \pm 160.3$ & $92.1 \pm 2.59$ \\
\hline
\end{tabular}

${ }^{1}$ Mean annual population growth rate; ${ }^{2}$ Probability of extinction; ${ }^{3}$ Mean extant population size

established from $<10$ founders (Taylor et al., 2005), and small founder populations do not necessarily lead to severe inbreeding depression (Jamieson et al., 2007), most geneticists consider that a large founder population is necessary to ensure sufficient genetic diversity, to avoid the potentially negative effects of inbreeding depression and to the capacity to adapt to environmental change in the long term (Frankham, 2005; Traill et al., 2010; Groombridge et al.,
2012; Jamieson \& Lacy, 2012; Keller et al., 2012). Genetic goals in population management often include the retention of $90 \%$ of genetic diversity over a specified time period (Frankham et al., 2002).

Based on the current composition of both reintroduced populations the baseline model predicted a retention of c. $80 \%$ of genetic diversity over 200 years. The fourth reinforcement scenario (of current reinforcement plans plus 
TABLE 6 Summary of results (mean \pm SD) of the Vortex simulation of scenarios of various catastrophic events on the $\mathrm{R}_{2}$ baseline population in Congo over a 200-year period.

\begin{tabular}{lccll}
\hline & & $\mathrm{P}(\mathrm{E})^{2}$ & Extant & $\begin{array}{l}\text { Gene } \\
\text { diversity (\%) }\end{array}$ \\
\hline Baseline (R2) & $0.007 \pm 0.043$ & 1.8 & $150 \pm 102.5$ & $85.3 \pm 7.33$ \\
Scenario C1 & $0.000 \pm 0.059$ & 13.5 & $55 \pm 46.6$ & $78.0 \pm 11.85$ \\
Scenario C2 & $-0.022 \pm 0.133$ & 99.0 & $5 \pm 2.0$ & $63.0 \pm 13.39$ \\
Scenario C3 & $-0.009 \pm 0.103$ & 62.5 & $26 \pm 27.9$ & $69.1 \pm 17.31$ \\
Scenario C4 & $-0.002 \pm 0.157$ & 47.7 & $106 \pm 103.1$ & $81.0 \pm 12.02$ \\
\hline
\end{tabular}

${ }^{1}$ Mean annual population growth rate; ${ }^{2}$ Probability of extinction; ${ }^{3}$ Mean extant population size

three subsequent reinforcements of three females and two males each time) was sufficient in both cases to achieve a $90 \%$ retention of genetic diversity. We did not include genetic management, which is used for small captive populations to ensure maximum retention of genetic diversity (Earnhardt et al., 2004), in our model. With the relatively intensive post-release monitoring techniques practised at both sites (King et al., 2012), some level of genetic management may be possible through population manipulation. Given that within gorilla society a few males dominate reproduction, and some fail to reproduce (Harcourt \& Stewart, 2007), genetic management in the reintroduced gorilla populations could be effected by manipulating each male's opportunities to breed.

\section{Modelling and reintroduction management}

The modelling showed that the populations have the capacity to persist for 200 years, with the probability of persistence and the retained genetic diversity increasing if the populations are gradually reinforced with new individuals over subsequent years. However, the exercise also shows that events beyond the control of management, particularly catastrophes but also factors such as the impacts of inbreeding depression, could jeopardize the populations and lead to their extinctions if they are frequent or severe enough. This conclusion is not unexpected and our results support the current directions in the management of the reintroduction programme, rather than suggesting significant modifications. The quantitative nature of the results does, however, highlight the magnitude of the potential negative impacts of disease-based catastrophes and inbreeding depression, suggesting firstly that reintroduction managers should ensure that pathogen surveillance protocols are regularly updated and applied, and secondly that realistic taxon-specific measurements of inbreeding depression should ideally be more widely available for modelling purposes, given their significant influence for predicting extinction risk (O'Grady et al., 2006).
The continued monitoring of the reintroduced populations will facilitate refinement of the model, particularly for highly sensitive input parameters such as birth rates and female mortality rates, and improve confidence in its predictions and its relevance to decision-making. The model could then provide guidance on issues such as the optimum number of individuals required for reinforcement of the reintroduced populations, and whether genetic management through the manipulation of male opportunities to breed is a strategy worth considering. Integration of such an adjustable model into the decision-making process could, if well structured and defined, lead to an adaptive management approach to reintroduction management (Armstrong et al., 2007; McCarthy et al., 2012).

\section{Monitoring and modelling slow-reproducing long-lived species}

In reintroduction programmes for slow-reproducing long-lived species, post-release monitoring needs to be undertaken over a relatively long time-frame, to gather even simple data on post-release survival and reproduction, which can give an indication of the initial success of the programme (King et al., 2012). To assess long-term success an evaluation of population viability is needed, which requires the development of a population model (Armstrong \& Reynolds, 2012; Seddon et al., 2012). For long-lived species the collection of the necessary demographic data, particularly mortality rates, could take decades. We were fortunate that our study species has a close relative, the eastern gorilla, one of the best-studied primates (Harcourt \& Stewart, 2007; Robbins et al., 2009). We were therefore able to compare our post-release monitoring data with large published datasets for eastern gorillas to verify that our data were realistic and to fill in gaps, particularly concerning adult mortality rates. If such data to develop a realistic population model are not available, reintroduction programmes for other long-lived species would have to wait for sufficient demographic data to be collected either through post-release monitoring or through demographic studies of wild populations.

\section{Acknowledgements}

We thank the Ministry of Forest Economy of the government of Congo, the Ministry of Water and Forests and the National Agency for National Parks of the government of Gabon, and The Aspinall Foundation, UK, for their long-term commitment to and funding of the reintroduction and protected area management projects. We also thank the Wildlife Conservation Society (USA), Florent Ikoli, Mbani Akangala Mankarika and Roland MissilouBoukaka (Congolese government), and Adrien Noungou, Pierre Ngavoura, Mamadou Ntsoumou and René Bazin 
Assaly (Gabonese government), for their contribution to protected area management and conservation on the Batéké Plateau. The information presented here results from 2 decades of dedicated work by numerous project staff without whom this programme would not have been possible, and to all of whom we are grateful.

\section{References}

Armstrong, D.P., Castro, I. \& Griffiths, R. (2007) Using adaptive management to determine requirements of reintroduced populations: the case of the New Zealand hihi. Journal of Applied Ecology, 44, 953-962.

Armstrong, D.P. \& Ewen, J.G. (2002) Dynamics and viability of a New Zealand robin population reintroduced to regenerating fragmented habitat. Conservation Biology, 16, 1074-1085.

Armstrong, D.P. \& Reynolds, M.H. (2012) Modelling reintroduced populations: the state of the art and future directions. In Reintroduction Biology: Integrating Science and Management (eds J.G. Ewen, D.P. Armstrong, K.A. Parker \& P.J. Seddon), pp. 165-222. Wiley-Blackwell, Chichester, UK.

Armstrong, D.P. \& Seddon, P.J. (2008) Directions in reintroduction biology. Trends in Ecology \& Evolution, 23, 20-25.

Asbjørnsen, E.J., SÆTher, B.-E., Linnell, J.D.C., Engen, S., Andersen, R. \& Bretten, A.T. (2005) Predicting the growth of a small introduced muskox population using population prediction intervals. Journal of Animal Ecology, 74, 612-618.

Atsalis, S. \& Margulis, S.W. (2006) Sexual and hormonal cycles in geriatric western lowland gorillas (Gorilla gorilla). International Journal of Primatology, 27, 1663-1687.

Beck, B., Walkup, K., Rodrigues, M., Unwin, S., Travis, D. \& Sto Inski, T. (2007) Best Practice Guidelines for the Re-introduction of Great Apes. IUCN/Species Survival Commission Primate Specialist Group, Gland, Switzerland.

Bradley, B.J., Robbins, M.M., Williamson, E.A., Steklis, H.D., Steklis, N.G., Eckhardt, N. et al. (2005) Mountain gorilla tug-of-war: silverbacks have limited control over reproduction in multimale groups. Proceedings of the National Academy of Sciences of the United States of America, 102, 9418-9423.

Britt, A., Welch, C., Katz, A., Iambana, B., Porton, I., Junge, R. et al. (2004) The restocking of captive-bred ruffed lemurs (Varecia variegata variegata) into the Betampona Reserve, Madagascar: methodology and recommendations. Biodiversity and Conservation, $13,635-657$.

Bustmante, J. (1996) Population viability analysis of captive and released bearded vulture populations. Conservation Biology, 10, 822-831.

Cramer, P.C. \& Portier, K.M. (2001) Modeling Florida panther movements in response to human attributes of the landscape and ecological settings. Ecological Modelling, 140, 51-80.

Dimond, W.J. \& Armstrong, D.P. (2007) Adaptive harvesting of source populations for translocation: a case study with New Zealand robins. Conservation Biology, 21, 114-124.

Earnhardt, J.M., Thompson, S.D. \& Schad, K. (2004) Strategic planning for captive populations: projecting changes in genetic diversity. Animal Conservation, 7, 9-16.

Frankham, R. (2005) Genetics and extinction. Biological Conservation, 126, 131-140

Frankham, R., Ballou, J.D. \& Briscoe, D.A. (2002) Introduction to Conservation Genetics. Cambridge University Press, Cambridge, UK.
Gaillard, J.M., Festa-Bianchet, M. \& Yoccoz, N.G. (1998) Population dynamics of large herbivores: variable recruitment with constant adult survival. Trends in Ecology \& Evolution, 13, $58-63$.

Gerald, C.N. (1995) Demography of the Virunga Mountain Gorilla. Princeton University, Princeton, USA.

Goossens, B., Funk, S.M., Vidal, C., Latour, S., Jamart, A., Ancrenaz, M. et al. (2002) Measuring genetic diversity in translocation programmes: principles and application to a chimpanzee release project. Animal Conservation, 5, 225-236.

Goossens, B., Setchell, J.M., Tchidongo, E., Dilambaka, E., Vidal, C., Ancrenaz, A. \& Jamart, A. (2005) Survival, interactions with conspecifics and reproduction in 37 chimpanzees released into the wild. Biological Conservation, 123, 461-475.

Groombridge, J.J., Raisin, C., Bristol, R. \& Richardson, D.S. (2012). Genetic consequences of reintroductions and insights from population history. In Reintroduction Biology: Integrating Science and Management (eds J.G. Ewen, D.P. Armstrong, K.A. Parker \& P.J. Seddon), pp. 395-440. Wiley-Blackwell, Chichester, UK.

Gusset, M., Jakoby, O., Mưller, M.S., Somers, M.J., Slotow, R. \& GRIMM, V. (2009) Dogs on the catwalk: modeling reintroduction and translocation of endangered wild dogs in South Africa. Biological Conservation, 142, 2774-2781.

Harcourt, A.H. (1995) Population viability estimates: theory and practice for a wild gorilla population. Conservation Biology, 9, 134-142.

Harcourt, A.H. \& Stewart, K.J. (2007) Gorilla Society: Conflict, Compromise, and Cooperation between the Sexes. University of Chicago Press, Chicago, USA.

IUCN (2002) IUCN Guidelines for Nonhuman Primate Reintroductions. IUCN/Species Survival Commission Re-introduction Specialist Group, Gland, Switzerland.

Jamieson, I.G. \& LACY, R.C. (2012) Managing genetic issues in reintroduction biology. In Reintroduction Biology: Integrating Science and Management (eds J.G. Ewen, D.P. Armstrong, K.A. Parker \& P.J. Seddon), pp. 441-476. Wiley-Blackwell, Chichester, UK.

Jamieson, I.G., Tracy, L.N., Fletcher, D. \& Armstrong, D.P. (2007) Moderate inbreeding depression in a reintroduced population of North Island robins. Animal Conservation, 10, 95-102.

Keller, L.F., Biebach, I., Ewing, S.R. \& Hoeck, E.A. (2012) The genetics of reintroductions: inbreeding and genetic drift. In Reintroduction Biology: Integrating Science and Management (eds J.G. Ewen, D.P. Armstrong, K.A. Parker \& P.J. Seddon), pp. 360-394. Wiley-Blackwell, Chichester, UK.

KING, T. (2004) Reintroduced western gorillas reproduce for the first time. Oryx , 38, 251-252.

KING, T. (2008) Detectability and conservation of De Brazza's monkey (Cercopithecus neglectus) in the Lesio-Louna and south-west Lefini Reserves, Batéké Plateau, Republic of Congo. Primate Conservation, 23, 39-44.

King, T., Chamberlan, C. \& Courage, A. (2005) Rehabilitation of orphan gorillas and bonobos in the Congo. International Zoo News, 52, 198-209.

King, T., Chamberlan, C. \& Courage, A. (2012) Assessing initial reintroduction success in long-lived primates by quantifying survival, reproduction and dispersal parameters: western lowland gorillas (Gorilla gorilla gorilla) in Congo and Gabon. International Journal of Primatology, 33, 134-149.

King, T., Chamberlan, C., Pearson, L. \& Courage, A. (2009) Gorilla sanctuaries and conservation in Congo and Gabon. International Zoo News, 56, 342-352.

King, T. \& Courage, A. (2007) Reintroduced western gorillas reproduce again. Oryx $, 41,14$ 
King, T. \& Courage, A. (2008) Western gorilla re-introduction to the Batéké Plateau region of Congo and Gabon. In Global Reintroduction Perspectives: Re-introduction Case-studies from Around the Globe (ed. P.S. Soorae), pp. 217-220. IUCN/Species Survival Commission Re-introduction Specialist Group, Abu Dhabi, UAE.

Kohlmann, S.G., Schmidt, G.A. \& Garcelon, D.K. (2005) A population viability analysis for the Island Fox on Santa Catalina Island, California. Ecological Modelling, 183, 77-94.

LACY, R.C. (1997) Importance of genetic variation to the viability of mammalian populations. Journal of Mammalogy, 78, 320-335.

LaCy, R.C., Borbat, M. \& Polla , J.P. (2003) VORTEX: A Stochastic Simulation of the Extinction Process. Version 9. Chicago Zoological Society, Brookfield, USA.

Maran, T., Põdra, M., Pólma, M. \& Macdonald, D.W. (2009) The survival of captive-born animals in restoration programmes-Case study of the endangered European mink Mustela lutreola. Biological Conservation, 142, 1685-1692.

Martínez-Abraín, A., Regan, H.M., Viedma, C., Villuendas, E., Bartolomé, M.A., Gómez, J.A. \& Oro, D. (2011) Costeffectiveness of translocation options for a threatened waterbird. Conservation Biology, 25, 726-735.

McCarthy, M.A., Armstrong, D.A. \& Runge, M.C. (2012). Adaptive management of reintroduction. In Reintroduction Biology: Integrating Science and Management (eds J.G. Ewen,

D.P. Armstrong, K.A. Parker \& P.J. Seddon), pp. 256-289. Wiley-Blackwell, Chichester, UK.

Miller, P.S. \& LACY, R.C. (2005) VORTEX: A Stochastic Simulation of the Extinction Process. Version 9.50 User's Manual. Conservation Breeding Specialist Group (IUCN Species Survival Commission), Apple Valley, MN, USA.

Nichols, J.D. \& Armstrong, D.P. (2012) Monitoring for reintroductions. In Reintroduction Biology: Integrating Science and Management (eds J.G. Ewen, D.P. Armstrong, K.A. Parker \& P.J. Seddon), pp. 223-255. Wiley-Blackwell, Chichester, UK.

O’Grady, J.J., Brook, B.W., Reed, D.H., Ballou, J.D., TONKYn, D.W. \& Frankham, R. (2006) Realistic levels of inbreeding depression strongly affect extinction risk in wild populations. Biological Conservation, 133, 42-51.

Parlato, E.H. \& Armstrong, D.P. (2012) An integrated approach for predicting fates of reintroductions with demographic data from multiple populations. Conservation Biology, 26, 97-106.

Pearson, L. \& King, T. (2008) Reproduction in a second population of reintroduced western gorillas. Oryx, 42, 14.

Peignot, P., Charpentier, M.J.E., Bout, N., Bourry, O., Massima, U., Dosimont, O. et al. (2008) Learning from the first release project of captive-bred mandrills Mandrillus sphinx in Gabon. Oryx, 42, 122-131.

Robbins, M.M., Bermejo, M., Cipolletta, C., Magliocca, F., Parnell, R.J. \& Stokes, E. (2004) Social structure and life-history patterns in Western Gorillas (Gorilla gorilla gorilla). American Journal of Primatology, 64, 145-159.

Robbins, M.M., Gray, M., Kagoda, E. \& Robbins, A.M. (2009) Population dynamics of the Bwindi mountain gorillas. Biological Conservation, 142, 2886-2895.

Robbins, M.M. \& Robins, A.M. (2004) Simulation of the population dynamics and social structure of the Virunga mountain gorillas. American Journal of Primatology, 63, 201-223.

Robbins, A.M., Robbins, M.M., Gerald-Steklis, N. \& Steklis, H.D. (2006) Age-related patterns of reproductive success among female mountain gorillas. American Journal of Physical Anthropology, 131, 511-521.

Robert, A. (2009) Captive breeding genetics and reintroduction success. Biological Conservation, 142, 2915-2922.
Schadt, S., Revilla, E., Wiegand, T., Knauer, F., Kaczensky, P., Breitenmoser, U. et al. (2002) Assessing the suitability of central European landscapes for the reintroduction of Eurasian lynx. Journal of Applied Ecology, 39, 189-203.

Schaub, M., Zink, R., Beissman, H., Sarrazin, F. \& Arlettaz, R. (2009) When to end releases in reintroduction programmes: demographic rates and population viability analysis of bearded vultures in the Alps. Journal of Applied Ecology, 46, 92-100.

Seddon, P.J., Armstrong, D.P. \& Maloney, R.F. (2007) Developing the science of reintroduction biology. Conservation Biology, 21, 303-312.

Seddon, P. J., Strauss, W. M. \& Innes, J. (2012) Animal translocations: what are they and why do we do them? In Reintroduction Biology: Integrating Science and Management (eds J.G. Ewen, D.P. Armstrong, K.A. Parker \& P.J. Seddon), pp. 1-32. Wiley-Blackwell, Chichester, UK.

Slotta-Bachmayr, L., Boegel, R., Kaczensky, P., Stauffer, C. \& WALZER, C. (2004) Use of population viability analysis to identify management priorities and success in reintroducing Przewalski's horses to southwestern Mongolia. Journal of Wildlife Management, $68,790-798$.

Somers, M.J. (1997) The sustainability of harvesting a warthog population: assessment of management options using simulation modelling. South African Journal of Wildlife Research, $27,37-43$

South, A., Rushton, S. \& Macdonald, D. (2000) Simulating the proposed reintroduction of the European beaver (Castor fiber) to Scotland. Biological Conservation, 93, 103-116.

Strum, S.C. (2005) Measuring success in primate translocation: a baboon case study. American Journal of Primatology, 65, 117-140.

SWART, J. \& LAWES, M.J. (1996) The effect of habitat patch connectivity on samango monkey (Cercopithecus mitis) metapopulation persistence. Ecological Modelling, 93, 57-74.

Tavecchia, G., Viedma, C., Martínez-Abraín, A., Bartolomé, M.-A., Gómez, J.A. \& Oro, D. (2009) Maximizing re-introduction success: assessing the immediate cost of release in a threatened waterfowl. Biological Conservation, 142, 3005-3012.

Taylor, S.S., Jamieson, I.G. \& Armstrong, D.P. (2005) Successful island reintroductions of New Zealand robins and saddlebacks with small numbers of founders. Animal Conservation, $8,415-420$.

Todd, C.R., Jenkins, S. \& Bearlin, A.R. (2002) Lessons about extinction and translocation: models for eastern barred bandicoots (Perameles gunnii) at Woodlands Historic Park, Victoria, Australia. Biological Conservation, 106, 211-223.

Traill, L.W., Brook, B.W., Frankham, R.R. \& Bradshaw, C.J.A. (2010) Pragmatic population viability targets in a rapidly changing world. Biological Conservation, 143, 28-34.

Tutin, C.E.G., Ancrenaz, M., Paredes, J., Vacher-Vallas, M., Vidal, C., Goossens, B. et al. (2001) The conservation biology framework of the release of wild-born orphaned chimpanzees into the Conkouati Reserve, Congo. Conservation Biology, 15, 1247-1257.

Tutin, C., Stokes, E., Boesch, C., Morgan, D., Sanz, C., Reed, T. et al. (2005) Regional Action Plan for the Conservation of Chimpanzees and Gorillas in Western Equatorial Africa. Conservation International, Washington, DC, USA

WakAmiYa, S.M. \& Roy, C.L. (2009) Use of monitoring data and population viability analysis to inform reintroduction decisions: peregrine falcons in the Midwestern United States. Biological Conservation, 142, 1767-1776.

Walsh, P.D., Tutin, C.E.G., Baillie, J.E.M., Maisels, F., Stokes, E.J. \& GAтti, S. (2008) Gorilla gorilla gorilla. In IUCN Red 
List of Threatened Species v. 2012.2. Http://www.iucnredlist.org [accessed 28 June 2013].

Watts, D.P. (1991) Mountain gorilla reproduction and sexual behavior. American Journal of Primatology, 24, 211-225.

YaEger, C.P. (1997) Orang-utan rehabilitation in Tanjung Putting National Park, Indonesia. Conservation Biology, 11, 802-805.

Yamagiwa, J. \& Kahekwa, J. (2001) Dispersal patterns, group structure, and reproductive parameters of eastern lowland gorillas at Kahuzi in the absence of infanticide. In Mountain Gorillas: Three Decades of Research at Karisoke (eds M.M. Robbins, P. Sicotte $\&$ K. Stewart), pp. 89-122. Cambridge University Press, Cambridge, UK.

\section{Biographical sketches}

Tony KIng plans, implements and evaluates reintroduction and conservation projects, particularly in the Republic of Congo and in Madagascar. He is committed to finding locally-relevant strategies for the conservation of threatened species and their habitats. CHRIS TELLE CHAMBERLAN has managed conservation projects in the Congo and Madagascar for the past 10 years. She has previously studied elephants and buffaloes in Odzala National Park, Congo, rehabilitated orphan chimpanzees in Congo, and worked with mountain gorillas in Rwanda. Amos Courage has been involved in the gorilla reintroduction programme since the first releases in 1996. 